\title{
FAKTOR-FAKTOR YANG BERHUBUNGAN DENGAN DETEKSI DINI KANKER LEHER RAHIM DI KECAMATAN GISTING KABUPATEN TANGGAMUS LAMPUNG
}

\author{
Christin Angelina Febriani \\ Fakultas Kesehatan Masyarakat, Universitas Malahayati Bandar Lampung \\ Email: christin.angelinaf@gmail.com
}

\begin{abstract}
Related Factors with Early Detection of Cervical Cancer at Gisting Subdistrict, Tanggamus District, Lampung. Cervical cancer is the second cancer issue which mostly found in all over the world with more than 500.000 newcases. This study is aimed to know the factors that influence the early detection of cervical cancer at Gisting subdistrict, Tanggamus district, Lampung. This study is quantitative with cross sectional design. The data used primary data. The population are all the fertile age couples which are 3795 , and the samples are 362 couples. Data were analized use logistic regression. Majority of the respondents did not do early detection of cervical cancer are 295 respondents $(81,5 \%)$ of all respondents. There are no relationship between husbands support ( $\mathrm{p}$ value 1,000 ), knowledge ( $\mathrm{p}$ value 0,357 ), with the early detection of cervical cancer at Gisting subdistrict, Tanggamus district, Lampung in 2016. The most dominant variable is family economic social status (p value <0,0001; OR 6,8). Suggested for Puskesmas Gisting to socialize about free payment for BPJS member to do IVA and paspsmear examination, and further improve the elucidation through persuade friends or families who ever did the IVA or papsmear examination to attend to elucidation, in order that raised the communities confidence to do the early detection (IVA or papsmear examination).
\end{abstract}

Keywords: Early detection of cervical cancer, IVA, Papsmear

\begin{abstract}
Abstrak: Faktor-Faktor yang Berhubungan dengan Deteksi Dini Kanker Leher Rahim di Kecamatan Gisting Kabupaten Tanggamus Lampung. Kanker leher rahim merupakan masalah kanker kedua yang paling banyak ditemukan hampir diseluruh dunia dengan lebih dari 500.000 kasus baru dan 250.000 kematian. Penelitian ini bertujuan untuk mengetahui faktor apakah yang memengaruhi deteksi dini kanker leher rahim di wilayah kecamatan Gisting kabupaten Tanggamus Lampung.Jenis penelitian ini merupakan kuantitatif dengan rancangan cross sectional. Populasi seluruh PUS berjumlah 3795 orang dan sampel yang digunakan berjumlah 362 orang. Data dianalisa menggunakan uji regresi logistic. Sebagian besar reponden tidak melakukan deteksi dini kanker leher rahim yaitu 295 responden $(81,5 \%)$ dari 362 responden seluruhnya. Tidak ada hubungan dukungan suami ( $p$-value 1,000), pengetahuan ( $p$-value 0,357$)$ dengan deteksi dini kanker leher rahim di wilayah kecamatan Gisting kabupaten Tanggamus Lampung tahun 2016. Hubungan yang paling dominan pada kanker leher rahim dengan deteksi dini kanker leher rahim di wilayah kecamatan Gisting kabupaten Tanggamus Lampung tahun2016 adalah status ekonomi dengan p-value < 0,001; OR 6,8. Disarankan bagi puskesmas Gisting untuk menyosialisasikan pemeriksaan IVA dan Papsmaer gratis bagi peserta BPJS dan lebih meningkatkan kegiatan sosial dengan pemeriksaan IVA gratis bagi masyarakat serta lebih meningkatkan penyuluhan kepada masyarakat sehingga timbul kepercayaan masyarakat agar mau melakukan pemeriksaan IVA dan papsmear dengan menghadirkan teman atau kerabat yang sudah pernah melakukan deteksi dini dengan IVA maupun papsmear.
\end{abstract}

Kata kunci: Deteksi dini kanker leher rahim, IVA, Papsmear

Kanker leher rahim adalah kanker yang paling banyak ditemukan pada wanita di negara berkembang, dimana sebanyak tiga perempat dari estimasi setengah juta kasus baru terjadi setiap tahun (Direktorat Pengadilan Penyakit Tidak Menular, 2013). Setiap tahun tidak kurang dari 15.000 kasus kanker leher rahim terjadi di Indonesia. Itu membuat kanker leher rahim disebut sebagai penyakit pembunuh nomor 1 di
Indonesia, hal tersebut dikarenakan tiap hari di Indonesia dari 40 wanita yang terdiagnosa menderita kanker leher rahim, 20 diantaranya meninggal dunia karena kanker leher rahim (Kementerian kesehatan RI, 2015).

Insiden kanker leher rahim sebenarnya dapat ditekan dengan melakukan upaya pencegahan primer seperti meningkatkan atau intensifikasi kegiatan penyuluhan kepada 
masyarakat untuk menjalankan pola hidup sehat, menghindari faktor risiko terkena kanker, melakukan immunisasi dengan vaksin Human Papillomavirus (HPV) dan diikuti dengan deteksi dini kanker leher rahim tersebut melalui pemeriksaan pap smear atau inspeksi visual dengan menggunakan asam acetat (IVA) (Sabrina, 2015). Saat ini cakupan deteksi dini kanker leher rahim di Indonesia melalui pap smear dan IVA masih sangat rendah (sekitar 5 $\%$ ), padahal cakupan deteksi dini yang efektif dalam menurunkan angka kesakitan dan angka kematian karena kanker leher rahim adalah $85 \%$ (Saslow, et al, 2012). Beberapa faktor hambatan pemeriksaan pap smear diantaranya adalah perilaku wanita usia subur yang enggan untuk diperiksa karena kurangnya pengetahuan wanita pasangan usia subur tentang pap smear rasa malu dan rasa takut untuk memeriksa organ reproduksi kepada tenaga kesehatan, faktor biaya khususnya pada golongan ekonomi lemah, sumber informasi dan fasilitas atau pelayanan kesehatan yang masih minim untuk melakukan pemeriksaan pap smear (Schiffman \& Solomon, 2013).

Pada tahun 2013 prevalensi kanker serviks di Indonesia adalah 98.692 kasus, propinsi Lampung 765 kasus, propinsi Sumatra Selatan 1500 kasus, propinsi Bangka Belitung 323 kasus, dibanding Sumatra Selatan propinsi Lampung masih rendah, tetapi hal tersebut mungkin karena kasus kanker di Lampung tidak semua terdeteksi (Riskesdas 2013). Pada kabupaten Tanggamus masih sangat sedikit sekali perempuan yang mau melakukan pemeriksaan Papsmear dan IVA.Pada tahun 2014 hanya sekitar 236 wanita yang mau melakukan pemeriksaan papsmear dan IVA. Sampai dengan bulan September tahun 2015 peserta yang mau melakukan pemeriksaan IVA dan papsmear hanya sekitar 246. Sebagai perbandingan di wilayah kabupaten Pesawaran tahun 2015, 539 perempuan yang melakukan deteksi dini kenker leher rahim melalui pemeriksaan IVA dan yang dinyatakan positif sebanyak 37 perempuan.

Pada Wilayah UPT Puskesmas Gisting terdapat sasaran pasangan usia subur (PUS) 379,5 dari bulan Januari sampai dengan Oktober 2015 terdapat kasus kanker leher rahim sebanyak 4 perempuan yang terdeteksi sudah pada stadium 3, dari sasaran 3795 PUS pada wilayah kerja UPT Puskesmas Gisting yang melakukan pemeriksaan IVA hanya sejumlah 39 orang dan 206 melakukan pemeriksaan papsmear. Berdasarkan data yang diperoleh pada saat pra survey dari 9 pekon di Kecamatan Gisting terdiri dari 90 orang responden alasan ibu tidak mau ikut serta dalam deteksi dini kanker leher dengan berbagai alasan, yaitu alasan karena malu 20\%, takut diperiksa 24,4\%, takut ketahuan penyakitnya $33,3 \%$, tidak mendapat izin suami $33,3 \%$, tidak mau 5,5\%, tidak ada waktu 3,3\%.

Penelitian ini bertujuan untuk mengetahui faktor apakah yang memengaruhi deteksi dini kanker leher rahim di wilayah kecamatan Gisting kabupaten Tanggamus Lampung.

\section{METODE PENELITIAN}

Jenis penelitian ini adalah kuantitatif. Penelitian ini dilaksanakan pada Maret-April 2015 di wilayah kerja UPT Puskesmas Gisting kabupaten Tanggamus. Rancangan penelitian yang digunakan adalah rancangan analitik dengan pendekatan cross sectional.

Populasi dalam penelitian ini sebanyak 3795 PUS, dan sampel sebesar 362 responden ditentukan menggunakan teknik Quota sampling. Data yang digunakan adalah data primer yang diambil secara langsung dengan menyebarkan kuesioner kepada responden.

\section{HASIL}

\section{A. ANALISIS UNIVARIAT}

Tabel 1. Distribusi Frekuensi Variabel Demografi pada Deteksi Dini Kanker Leher Rahim

\begin{tabular}{ccc}
\hline \multicolumn{2}{c}{ Variabel } & Jumlah (\%) \\
\hline Usia & & \\
- & Tidak berisiko & $128(35,4 \%)$ \\
- Berisiko & $234(64,6 \%)$ \\
Pendidikan & \\
- SD & $66(16,2 \%)$ \\
- SMP & $119(33,9 \%)$ \\
- SMA & $148(40,9 \%)$ \\
- D3/PT & $29(8,0 \%)$ \\
Pekerjaan & \\
- Tidak bekerja & $158(43,6 \%)$ \\
- Bekerja & $204(56,4 \%)$ \\
\hline
\end{tabular}

Berdasarkan tabel di atas terlihat bahwa sebaran responden yang memiliki usia berisiko untuk terkena kanker leher rahim sebanyak 64,6\% dengan pendidikan terakhir yang dimiliki ada pada SMP $(33,9 \%)$ dan SMA $(40,9 \%)$. Distribusi pekerjaan memperlihatkan proporsi yang berimbang antara responden yang bekerja dengan tidak bekerja. 
Tabel 2. Distribusi Frekuensi Variabel Psikologi pada Deteksi Dini Kanker Leher Rahim

\begin{tabular}{rc}
\hline \multicolumn{1}{c}{ Variabel } & Jumlah (\%) \\
\hline Status ekonomi keluarga & \\
$-\quad \geq$ UMR & $128(35,4 \%)$ \\
$-\quad<$ UMR & $234(64,6 \%)$ \\
Dukungan suami & \\
- Didukung & $185(51,1 \%)$ \\
- Tidak didukung & $177(48,9 \%)$ \\
Sikap & \\
- Positif ( \median) & $174(48,1 \%)$ \\
$-\quad$ Negatif (< median) & $188(51,9 \%)$ \\
\hline
\end{tabular}

Pada tabel yang terlihat di atas, diketahui bahwa status ekonomi keluarga responden penelitian ini masih berada di bawah UMR Kabupaten Tanggamus sebanyak 64,6\%. Responden yang mendapat dukungan suami untuk melakukan deteksi dini kanker leher rahim sudah cukup baik, yaitu sebanyak $51,1 \%$, sementara yang memiliki sikap positif hanya sebanyak $48,1 \%$.

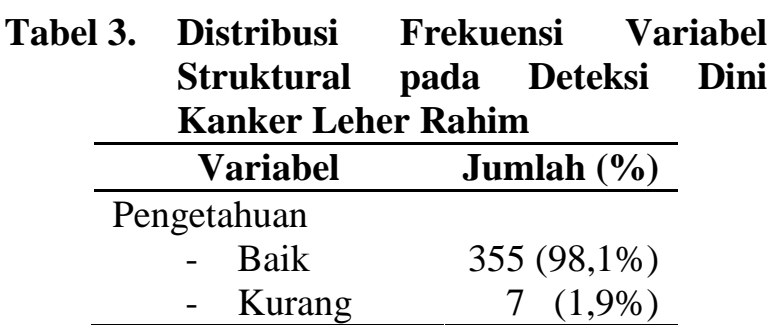

Pada tabel 3 di atas memperlihatkan bahwa sebagian besar responden telah memiliki pengetahuan yang baik tentang deteksi dini kanker leher rahim sebanyak $98,1 \%$.

Tabel 4 memperlihatkan bahwa responden yang mendapatkan informasi terkait deteksi dini penyakit ini hanya sebanyak $58 \%$ dan peranan kader kesehatan sebanyak 62,2\%.

Tabel 4. Distribusi Frekuensi Isyarat untuk Bertindak pada Deteksi Dini Kanker Leher Rahim

\begin{tabular}{cc}
\hline Variabel & Jumlah (\%) \\
\hline Informasi yang didapat & \\
$-\quad$ Ya & $210(58,0 \%)$ \\
- Tidak & $152(42,0 \%)$ \\
Peran kader kesehatan & \\
$-\quad$ Ya & $225(62,2 \%)$ \\
\hline
\end{tabular}

\begin{tabular}{ll}
\hline - Tidak & $137(37,8 \%)$ \\
\hline
\end{tabular}

Tabel 5. Distribusi Frekuensi Hambatan Tindakan Preventif pada Deteksi Dini Kanker Leher Rahim

\begin{tabular}{ll}
\hline \multicolumn{1}{c}{ Variabel } & Jumlah (\%) \\
\hline Nilai-nilai (malu) & $200(55,2 \%)$ \\
- Tidak & $162(44,8 \%)$ \\
- Ya & \\
Takut akan menerima diagnosa & \\
penyakit & $110(30,4 \%)$ \\
- Ya & $252(69,6 \%)$ \\
- Tidak & \\
\hline
\end{tabular}

Pada tabel lainnya, diketahui bahwa responden yang memiliki nilai-nilai malu dan ketakutan menerima diagnosis penyakit masih cukup rendah, yaitu $44,8 \%$ dan $30,4 \%$.

Tabel 6. Distribusi Frekuensi Deteksi Dini Kanker Leher Rahim pada Deteksi Dini Kanker Leher Rahim

\begin{tabular}{|c|c|}
\hline \multicolumn{2}{|l|}{$\begin{array}{l}\text { Variabel } \\
\end{array}$} \\
\hline Deteksi Dini Kanker Leher Rahim & \\
\hline - Melakukan deteksi dini & $67(18,5 \%)$ \\
\hline $\begin{array}{l}\text { - Tidak melakukan deteksi } \\
\text { dini }\end{array}$ & $295(81,5 \%)$ \\
\hline
\end{tabular}

Tabel di atas menunjukkan bahwa partisipasi responden untuk melakukan deteksi dini kanker leher rahim masih rendah, yaitu sebanyak $18,5 \%$.

\section{B. ANALISIS BIVARIAT}

Analisis bivariat yang dihasilkan seperti yang terlihat pada tabel dibawah, menunjukkan bahwa terdapat 9 dari 11 variabel ditemukan adanya hubungan dengan keputusan responden untuk melakukan deteksi dini kanker leher rahim di wilayah Gisting. Dua variabel tidak ditemukan adanya hubungan dengan deteksi dini kanker leher rahim adalah variabel dukungan suami dan pengetahuan. 
Tabel 7. Analisis Bivariabel Faktor-faktor yang Berhubungan denganDeteksi Dini Kanker Leher Rahim

\begin{tabular}{|c|c|c|c|c|c|}
\hline \multirow{2}{*}{ Variabel } & \multicolumn{2}{|c|}{$\begin{array}{c}\text { Deteksi Dini } \\
\text { Kanker Leher Rahim }\end{array}$} & \multirow{2}{*}{ Jumlah } & \multirow{2}{*}{$p$-value } & \multirow{2}{*}{$\begin{array}{c}\text { OR } \\
(95 \% \mathrm{CI})\end{array}$} \\
\hline & $\begin{array}{c}\text { Deteksi } \\
(\%)\end{array}$ & $\begin{array}{c}\text { Tidak } \\
\text { Deteksi }(\%) \\
\end{array}$ & & & \\
\hline \multicolumn{6}{|l|}{ Usia } \\
\hline - Tidak berisiko & $16(12,5)$ & $112(87,5)$ & 128 & 0,042 & 0,5 \\
\hline - Berisiko & $51(21,8)$ & $183(78,2)$ & 234 & & $(0,3-0,9)$ \\
\hline \multicolumn{6}{|l|}{ Pendidikan } \\
\hline - Tinggi & $45(25,4)$ & $132(74,6)$ & 177 & 0,001 & 2,5 \\
\hline - Rendah & $22(11,9)$ & $163(88,1)$ & 185 & & $(1,4-4,4)$ \\
\hline \multicolumn{6}{|l|}{ Pekerjaan } \\
\hline - Tidak bekerja & $43(27,2)$ & $115(72,8)$ & 158 & $<0,001$ & 2,8 \\
\hline - Bekerja & $24(11,8)$ & $180(88,2)$ & 204 & & $(1,6-4,7)$ \\
\hline \multicolumn{6}{|l|}{ Status ekonomi keluarga } \\
\hline$-\quad \geq$ UMR & $48(37,5)$ & $80(62,5)$ & 128 & $<0,001$ & 6,8 \\
\hline$-\quad<\mathrm{UMR}$ & $19(8,1)$ & $215(91,9)$ & 234 & & $(3,8-12,2)$ \\
\hline \multicolumn{6}{|l|}{ Dukungan suami } \\
\hline - Didukung & $34(18,4)$ & $151(81,6)$ & 185 & 1,000 & 1,0 \\
\hline - Tidak didukung & $33(18,6)$ & $144(81,4)$ & 177 & & $(0,6-1,7)$ \\
\hline \multicolumn{6}{|l|}{ Sikap } \\
\hline - Positif & $41(23,6)$ & $133(76,4)$ & 174 & 0,025 & 1,9 \\
\hline - Negatif & $26(13,8)$ & $162(86,2)$ & 188 & & $(1,1-3,3)$ \\
\hline \multicolumn{6}{|l|}{ Pengetahuan } \\
\hline - Baik & $67(18,9)$ & $288(81,1)$ & 355 & 0,357 & - \\
\hline - Kurang & 0 & $7(100)$ & 7 & & \\
\hline \multicolumn{6}{|l|}{ Informasi yang didapat } \\
\hline - Ya & $51(24,3)$ & $159(75,7)$ & 210 & 0,001 & \\
\hline - Tidak & $16(10,5)$ & $136(89,5)$ & 152 & & $(1,5-5,0)$ \\
\hline \multicolumn{6}{|l|}{ Peran kader kesehatan } \\
\hline - Ya & $51(22,7)$ & $174(77,3)$ & 225 & 0,013 & 2,2 \\
\hline - Tidak & $16(11,7)$ & $121(88,3)$ & 137 & & $(1,2-4,1)$ \\
\hline \multicolumn{6}{|l|}{ Nilai-nilai (malu) } \\
\hline - Tidak & $50(25,0)$ & $150(75,0)$ & 200 & 0,001 & 2,8 \\
\hline$-\mathrm{Ya}$ & $17(10,5)$ & $145(89,5)$ & 162 & & $(1,6-5,2)$ \\
\hline \multicolumn{6}{|l|}{$\begin{array}{l}\text { Takut akan menerima } \\
\text { diagnosa penyakit }\end{array}$} \\
\hline - Ya & $46(41,8)$ & $64(58,2)$ & 110 & $<0,001$ & 7,9 \\
\hline - Tidak & $21(8,3)$ & $231(91,7)$ & 252 & & $(4,4-14,2)$ \\
\hline
\end{tabular}

\section{ANALISIS MULTIVARIAT}

Hasil akhir analisis multivariabel menggunakan regresi logistk ini didapatkan bahwa terdapat 7 variabel yang dinyatakan sebagai faktor-faktor yang mempengaruhi keputusan responden untuk melakukan deteksi dini kanker leher rahim. Variabel yang paling dominan mempengaruhi deteksi dini adalah status ekonomi keluarga dengan odds sebesar 6,0 kali (95\% CI: 2,9-12,2).
Tabel 8. Analisis Multivariabel dengan Pemodelan Akhir Faktor-faktor yang Berhubungan dengan Deteksi Dini Kanker Leher Rahim

\section{Variabel p-value OR(95\% CI)}

\begin{tabular}{|c|c|c|c|}
\hline \multicolumn{4}{|l|}{ Usia } \\
\hline- & $\begin{array}{l}\text { Tidak berisiko } \\
\text { Berisiko }\end{array}$ & 0,155 & $\begin{array}{c}0,6 \\
(0,3-1,2)\end{array}$ \\
\hline \multicolumn{4}{|c|}{ Pekerjaan } \\
\hline & $\begin{array}{l}\text { Tidak bekerja } \\
\text { Bekerja }\end{array}$ & $<0,001$ & $\begin{array}{c}4,2 \\
(2,1-8,6)\end{array}$ \\
\hline \multicolumn{4}{|c|}{ Status ekonomi } \\
\hline
\end{tabular}




\begin{tabular}{|c|c|c|}
\hline Variabel & p-value & OR(95\% CI $)$ \\
\hline $\begin{array}{ll}- & \geq \text { UMR } \\
- & <\text { UMR }\end{array}$ & & $(2,9-12,2)$ \\
\hline $\begin{array}{c}\text { Informasi yang didapat } \\
-\quad \text { Ya } \\
-\quad \text { Tidak }\end{array}$ & 0,249 & $\begin{array}{c}1,6 \\
(0,7-3,3)\end{array}$ \\
\hline $\begin{array}{c}\text { Peran kader kesehatan } \\
-\quad \text { Ya } \\
-\quad \text { Tidak }\end{array}$ & 0,029 & $\begin{array}{c}2,4 \\
(1,1-5,2)\end{array}$ \\
\hline $\begin{array}{c}\text { Nilai-nilai (malu) } \\
\text { - } \quad \text { Tidak } \\
-\quad \text { Ya }\end{array}$ & 0,019 & $\begin{array}{c}2,5 \\
(1,2-5,3)\end{array}$ \\
\hline $\begin{array}{l}\text { Takut akan menerima } \\
\text { diagnosa penyakit } \\
\text { - Ya } \\
\text { - Tidak }\end{array}$ & $<0,001$ & $\begin{array}{c}5,1 \\
(2,6-10,5)\end{array}$ \\
\hline
\end{tabular}

obyek tertentu, yang sudah melibatkan faktor pendapat dan emosi yang bersangkutan (senangtidak senang, setuju-tidak setuju, baik-tidak baik, dan sebagainya). Hasil penelitian ini sejalan dengan penelitian Adi (2011) sikap wanita dewasa di wilayah Kabupaten Banyumas memiliki hubungan yang signifikan dengan pemeriksaan deteksi dini kanker serviks. Sejalan pula dengan penelitian Martini yang mengatakan bahwasikap berhubungan kuat dengan tindakan pemeriksaan pap smear di puskesmas Sukawati II tahun 2013. Peneliti berasumsi bahwa sikap positif dari individu tidak serta merta berujung -pada perilaku kesehatan yang baik pula, dalam hal ini adalah melakukan IVA atau papsmear. Berbagai faktor perancu akan menghampiri dan dapat merubah sikap positif tadi menjadi perilaku yang tidak positif. Faktor perancu tersebut terkait dengan faktor status sosial ekonomi dan takut

\section{PEMBAHASAN}

\section{a. Hubungan Pengetahuan dengan Deteksi Dini Kanker Leher Rahim}

Penelitian terkait oleh Maharsie dan Indarwati (2012) terhadap perempuan 30-50 tahun di kelurahan Jebres terhadap 66 responden menunjukkan bahwa ada hubungan yang signifikan antara pengetahuan tentang kanker serviks dengan keikutsertaan ibu melakukan tes IVA. Berdasarkan hasil penelitian ini dapat dikatakan bahwa keputusan untuk melakukan deteksi dini kanker leher rahim tidak hanya berasal dari faktor pengetahuan, namun terdapat confounding factors yang dapat merancukan pengetahuan yang telah baik mengenai deteksi dini, menjadi eksekusi perilaku yang tidak tepat yaitu menolak melakukan deteksi dini berupa IVA atau Papsmear. Sehingga petugas kesehatan perlu lebih giat menjalankan tugas konselor bagi PUS guna menimbulkan kepercayaan tentang pentingnya deteksi dini ini. Sebab banyak PUS yang tahu (tingkat pengetahuan pertama dari individu) tetapi tidak mau; atau PUS yang tidak tahu dan tidak mau melakukan deteksi dini kanker leher rahim. Konseling yang dilakukan dengan pendekatan secara mendalam dan memberikan penyuluhan kepada para perempuan tentang pentingnya deteksi dini kanker leher rahim bagi kesehatan reproduksi dan bagi kelangsungan hidupnya.

\section{b. Hubungan Sikap dengan Deteksi Dini Kanker Leher Rahim \\ Menurut Notoatmodjo (2014) Sikap} merupakan reaksi atau respon seseorang yang masih tertutup terhadap suatu stimulasi atau jika di ketahui penyakitnya. Sehingga walaupun responden bersikap positif namun tetap enggan melakukan deteksi dini kanker leher rahim. Namun, sebagian besar individu yang berangkat dari pengetahuan, persepsi dan sikap yang positif terhadap suatu topik masalah kesehatan. Maka, kans untuk terjadi eksekusi perilaku kesehatan yang positifpun akan lebih besar.

\section{c. Hubungan Pendidikan dengan Deteksi Dini Kanker Leher Rahim}

Pendidikan adalah proses di mana semua kemampuan manusia (bakat dan kemampuan yang diperoleh) yang dapat dipengaruhi oleh pembiasaan, disempurnakan dengan kebiasaankebiasaan yang baik melalui sarana yang secara artistik dibuat dan dipakai oleh siapapun untuk membantu orang lain atau dirinya sendiri mencapai tujuan yang ditetapkan yaitu kebiasaan yang baik (Adler, 2011).

Pendidikan berkaitan erat dengan segala sesuatu yang bertalian dengan perkembangan manusia mulai perkembangan fisik, kesehatan, keterampilan, pikiran, perasaan, kemauan, sosial sampai kepada perkembangan iman. Berdasarkan peneitian ini, peneliti berpendapat bahwa pada responden dengan tingkat pendidikan tinggi yang melakukan deteksi dini kanker leher rahim karena perempuan yang berpendidikan tinggi cenderung lebih memperhatikan diri dan keluarganya. Pendidikan dapat mempengaruhi sesorang dalam mengambil keputusan dalam deteksi dini kanker leher rahim semakin tinggi pendidikan semakin baik pengetahuan dan akan semakin bijaksana dalam mengambil keputusan dalam deteksi dini kanker leher rahim . sedangkan perempuan dengan pendidikan rendah yang melakukan deteksi dini kanker leher rahim 
menurut pendapat peneliti pendidikan akan mempengaruhi pengtahuan seseorang dan pendidikan dan pengetahuan tidak hanya bias di dapat dari pendidikan secara formal melainkan ada yang didapat secara informal salah satunya pendidikan yang didapat responden berasal dari kegiatan yang sering dilakukan secara rutin seperti pada kegiatan posyandu, pengajian, pertemuan PKK yang secara tidak langsung dapat meningkatkan pengetahuan perempuan. Sedangkan pada hasil penelitian sebanyak 163 responden berpendidikan rendah tidak melakukan deteksi dinikanker leher rahim karena dapat disebabkan karena pada pendidikan rendah dimana pengetahuan dan cara pandang seseorang lebih sempit dan tidak mudah untuk menerima ide atau saran yang baru sehingga responden lebih memilih untuk tidak melakukan deteksi dini kanker leher rahim. Tingkat pendidikan merupakan salah satu faktor yang sangat menentukan pengetahuan dan persepsi seseorang terhadap pentingnya suatu hal termasuk pentingnya deteksi dini kanker leher rahim, disebabkan seseorang yang berpendidikan tinggi akan lebih luas pandangannya dan lebih mudah menerima ide dan tata cara kehidupan baru. Sehingga dapat disimpulkan bahwa orang yang berpendidikan tinggi akan melakukan deteksi dini kanker leher rahim.

\section{d. Hubungan Umur dengan Deteksi Dini Kanker Leher Rahim}

Semakin dewasa dan bertambah umur seseorang maka semakin bertambah pula daya tanggapnya, melalui perjalanan umurnya semakin dewasa individu yang bersangkutan akan melakukan adaptasi perilaku terhadap lingkungannnya. Pernyataan ini menunjukkkan bahwa dengan umur responden yang makin dewasa akan mudah beradaptasi dengan lingkungan yang adadisekitarnya dimana mereka mau mengikuti perilaku dalam mengikuti deteksi dini kanker leher rahim dikarenakan keterpaparan dengan sumber informasi, pengaruh suami dan teman yang akan bertambah sejalan dengan bertambahnya umur.

Berdasarkan hasil penelitian sebanyak 183 responden yang berisiko, tetapi tidak melakukan deteksi dini kanker leher rahim. Hal ini dapat disebabkan oleh faktor sosial ekonomi, rasa malu dan rasa takut akan menerima diagnose suatu penyakit. Semakin dewasa umur seharusnya semakin matang dalam berfikir dan akan semakin bijaksana dalam melakukan deteksi dini kanker leher rahim. Namun tidak menutup kemungkinan bahwa usia individu yang diharapkan kedewasaan dan pemikirannya pun sepadan dengan usianya, justru menolak menyadari dan dengan rendah hati mau melakukan deteksi dini. Oleh sebab itu dibutuhkan peran petugas kesehatan untuk dapat memberikan informasi yang benar, tepat dan sesuai dengan usia reponden sehingga respnden termotivasi untuk dapat melakukan deteksi dini kanker leher rahim.

\section{e. Hubungan Pekerjaan dengan Deteksi Dini Kanker Leher Rahim}

Menurut Notoadmodjo (2011) pekerjaan akan berpengaruh terhadap sesuatu yang dikerjakan untuk mendapatkan nafkah atau pencaharian masyarakat yang sibuk dengan kegiatan atau pekerjaan sehari-hari akan memiliki waktu yang lebih untuk memperoleh informasi. Hal ini berkaitan dengan tingkat penghasilan seseorang. Dengan demikian dapat dikatakan bahwa mata pencaharian dapat mempengaruhi partisipasi masyarakat dalam pembangunan.

Hasil penelitian didapati bahwa ibu yang tidak bekerja tidak melakukan pemeriksaan kanker leher rahim sebanyak 115 responden dikarenakan faktor, informasi tentang deteksi dini, sosial ekonomi, dan pendidikan sehingga ibu tidak melakukan deteksi dini kanker leher rahim. Menurut hasil penelitian ini ibu yang bekerja akan memiliki waktu luang yang lebih sedikit dengan ibu yang tidak bekerja dalam melakukan deteksi dini kanker leher rahim, untuk hal tersebut sebaiknya petugas kesehatan memberikan pelayanan deteksi dini kanker leher rahim diwaktu-waktu dimana perempuan yang bekerja memiliki waktu senggang, misalnya hari libur atau sore hari. Sedangkan bagi ibu yang tidak bekerja (aktivitas penuh di rumah) namun enggan melakukan IVA atau papsmear dapat dikarenakan alasan keuangan. Ibu yang merasa tidak memiliki penghasilan sendiri, akan sayang menggelontorkan uang hanya sekedar melakukan pemeriksaan, yang menurutnya tidak penting sebab ia tidak merasa sedang sakit. Sebab pekerjaan dan penghasilan keluarga merupakan karakteristik pendukung individu untuk memanfaatkan pelayanan kesehatan.

\section{f. Hubungan nilai-nilai (Malu) dengan Deteksi Dini Kanker Leher Rahim}

Hal ini sejalan dengan penelitian yang dilakukan oleh Sulistiowati (2014) malu merupakan alasan kedua setelah alasan Sambungan Squama Kolumner (SSK) tidak kelihatan dimana wanita memiliki alasan untuk tidak dilakukan pemeriksaan deteksi dini kanker leher rahim melalui tes IVA dari 1055 wanita 
yang tidak dilakukan pemeriksaan IVA 248 $(23,5 \%)$ karena alasan malu.

Peneliti berasumsi bahwa malu adalah salah satu bentuk emosi manusia. Malu memiliki arti beragam, yaitu sebuah emosi, pengertian, pernyataan, atau kondisi yang dialami manusia akibat sebuah tindakan yang dilakukannya sebelumnya, dan kemudian ingin ditutupinya. Masih banyak perempuan yang enggan untuk melakukan deteksi dini kanker leher rahim karena berbagai alasan salah satunya adalah malu untuk membuka vagina nya saat dilakukan pemeriksaan IVA atau Pap smear untuk deteksi dini kanker leher rahim.

\section{g. Hubungan Sosial Ekonomi Keluarga dengan Deteksi Dini Kanker Leher Rahim}

Status sosial ekonomi adalah kedudukan atau posisi seseorang dalam masyarakat, status sosial ekonomi adalah gambaran tentang keadaan seseorang atau suatu masyarakat yang ditinjau dari segi sosial ekonomi, gambaran itu seperti tingkat pendidikan, pendapatan dan sebagainya. Status ekonomi adalah kedudukan seseorang atau keluarga di masyarakat berdasarkan pendapatan per bulan. Status ekonomi dapat dilihat dari pendapatan yang disesuaikan dengan harga barang pokok. Hal ini sejalan dengan analisa Gustiana et all (2015) perempuan yang memiliki pendapatan tingggi berpeluang lebih baik melakukan pencegahan terhadap kanker leher rahim, dibandingkan dengan perempuan yang berpenghasilan rendah.

\section{h. Hubungan Dukungan Suami dengan Deteksi Dini Kanker Leher Rahim}

Menurut House dan Kahn dalam Friedman (2010) dukungan keluarga adalah sebuah proses yang terjadi sepanjang masa kehidupan, sifat dan jenis dukungan berbeda dalam berbagai tahaptahap siklus kehidupan. Dukungan keluarga dapat berupa dukungan sosial internal, seperti dukungan dari suami, istri atau dukungan dari saudara kandung dan dapat juga berupa dukungan keluarga eksternal bagi keluarga inti. Dukungan keluarga membuat keluarga mampu berfungsi dengan berbagai kepandaian dana akal. Sebagai akibatnya, hal ini meningkatkan kesehatan dan adaptasi keluarga.

Penelitian ini tidak sejalan dengan penelitian yang dilakukan Linadi (2013), menunjukkan bahwa dukungan suami memiliki hubungan yang signifikan dengan ke ikut sertaan PUS dalam deteksi dini kanker leher rahim di perumahan Pucung Gading Semarang. Juga penelitian yang dilakukan Gustiana, Dewi,
Nurchayati (2015) Dukungan suami mempunyai hubungan dengan perilaku pencegahan kanker serviks pada wanita usia subur. Berdasarkan hasil penelitian dimana pada responden yang didukung suami tetapi masih tetap tidak melakukan deteksi dini kanker leher rahim, hal ini bisa dikarenakan walaupun mendapat dukungan suami, namun ketika responden tidak mau dan merasa tidak siap melakukan deteksi dini, pada akhirnya akan mempengaruhi keputusan responden dalam melakukan deteksi dini kanker leher rahim.

\section{i. Hubungan Peran Kader Kesehatan dengan Deteksi Dini Kanker Leher Rahim}

Seorang kader kesehatan harus bisa memberi contoh, member informasi dan penyuluhan kesehatan kepada masyarakat dilingkungan tempat tinggalnya melalui pertemuan-pertemuan di desanya, baik itu informasi kesehatan dari puskesamas maupun dari dinas kesehatan langsung. Peran aktif kader dapat mempengaruhi mau atau tidaknya seorang perempuan untuk meakukan deteksi dini kanker leher rahim.

Kader kesehatan mempunyai tugas yang mulia, kader diharapkan dapat berperan sebagai pemberi informaasi kesehatan kepada masyarakat, penggerak masyarakat untuk melaksanakan pesan-pesan kesehatan seperti mendatangi posyandu dan melaksanakan hidup bersih dan sehat, dan sebagainya. Selain dari pada itu kader juga dapat berperan sebagai orang yang pertama kali menemukan jika ada masalah kesehatan di daaerahnya dan segeramelaporkan kesehatan setempat. Kader merupakan penghubung antara masyarakat dengan tenaga kesehatan karena kader selalu berada di tengah-tengah masyarakat.

\section{j. Hubungan Informasi yang Didapat dengan Deteksi Dini Kanker Leher Rahim}

Informasi yang diperoleh tentang kanker leher rahim dapat diperoleh melalui penyuluhan oleh tenaga kesehatan melalui pertemuan di pengajian, pertemuan di tingkat desa, informasi dari teman atau tetangga maupun keluarga yang pernah melakukan pemeriksaan deteksidini kanker leher rahim selain itu informasi juga dapat diperoleh melalui poster-poster yang disediakan oleh pemerintah daerah. Selain itu pila dapat diperoleh melalui sarana komunikasi. Sebagai sarana komunikasi, berbagai bentuk media masa seperti televisi, radio, surat khabar, majalah, dll. Mempunyai pengaruh besar dalam pembentukan opini dan kepercayaan orang. Dalam penyampaian informasi sebagai tugas pokoknya, 
media masa membawa pula pesan-pesan yang berisi sugesti yang dapat mengarahkan opini seseorang. Adanya informasi baru mengenai sesuatu hal memberikan landasan kognitif baru bagi terbentuknya sikap terhadap hal tersebut apabila cukup kuat akan memberi dasar afekif dalam menilai sesuatu hal sehingga terbentuklah arah sikap tertentu. Peneliti berasumsi bahwa sebagai sarana komunikasi, berbagai media massa seperti televisi, radio, mempunyai pengaruh besar dalam pembentukan opini dan kepercayaan orang. Adanya informasi baru mengenai sesuatu hal memberikan landasan kognitif baru bagi terbentuknya sikap terhadap hal tersebut. Pesan-pesan sugestif yang dibawa informasi tersebut.

\section{k. Hubungan Takut Didiagnosa Penyakit Kanker Leher Rahim dengan Deteksi Dini Kanker Leher Rahim}

Menurut Husada (2011), ancaman suatu penyakit dipersepsikan secara berbeda oleh setiap individu, seperti penyakit kanker leher rahim, ada yang takut tertular penyakit tersebut, tetapi ada juga yang mengganggap penyakit tersebut tidak begitu parah, ataupun individu merasa tidak akan tertular dikarenakan diantara anggota keluarganya tidak ada yang menderita penyakit tersebut. Keputusan untuk mengambil tindakan/ upaya penanggulangan atau pencegahan penyakit itu tergantung dari persepsi individu tentang keuntungan dari tindakan tersebut baginya, besar/kecilnya hambatan untuk melaksanakan tindakan itu serta pandangan individu tentang kemampuan diri sendiri.

Menurut hasil penelitian meskipun pendidikan tinggi, sosial ekonomi tinggi, pengetahuan baik, mendapat dukungan suami, mendapat informasi yang cukup, mendapat ajakan dari kader kesehatan. Akan tetapi jika mempunyai rasa takut akan membuat seorang perempuan tidak mau melakukan deteksi dini kanker leher rahim. Persepsi tentang ancaman penyakit dan upaya penanggulangannnya dipengaruhi oleh latar belakang sosio demografi individu. Untuk menguatkan keputusan bertindak, diperlukan faktor pencetus, jika faktor pencetus itu cukup kuat dan individu merasa tidak sia-sia, barulah individu itu benar-benar melaksanakan tindakan yang dianjurkan guna mencegah penyakit tersebut. Untuk hal tersebut diperlukan sikap dari petugas kesehatan untuk tidak bosan memberikan penyuluhan tentang kanker leher rahim kepada masyarakat sehingga timbulah kesadaran tentang pentingnya deteksi kanker leher rahim.

\section{Variabel yang paling dominan}

Faktor yang paling dominan pada deteksi dini kanker leher rahim di wilayah kecamatan Gisting Kabupaten Tanggamus lampung tahun 2016 adalah status sosial ekonomi keluarga. Menurut analisa Gustiana et all (2015), perempuan yang memiliki pendapatan tingggi berpeluang lebih baik melakukan pencegahan terhadap kanker leher rahim, dibandingkan dengan perempuan yang berpenghasilan rendah. Menurut Rasjidi, wanita di kelas sosioekonomi yang paling rendah memiliki faktor risiko lima kali lebih besar daripada wanita di kelas yang paling tinggi. Hubungan ini mungkin dikacaukan oleh hubungan seksual dan akses ke sistem pelayanan kesehatan.

Dapat dikatakan bahwa seseorang dengaan sosial ekonomi yang baik akan lebih mudah memperoleh pendidikan yang cukup, dan lebih mudah mendapat informasi yang dibutuhkan, dengan demikian akan lebih mudah menentukan tindakan preventif apa yang akan dipilih dalam pemenuhan kebutuhan kesehatannya karena dengan dukungan sosial ekonomi yang baik akan mendukung semua aspek yang mempengaaruhi dalam deteksi dini kanker leher rahim. Peran sosial ekonomi dalam bidang kesehatan adalah salah satu upaya untuk membuat perilaku masyarakat itu kondusif untuk kesehatan yang artinya sisioekonomidpapat mendorong seorang mendepat pendidikan dan pengetauan yang cukup tentang kanker leher rahim sehingga lebih mudah seseorang menerima informasi tentang kanker leher rahim yang dapat mempengeruhi sikapnya dalam deteksi dini kanker leher rahim.

\section{SIMPULAN}

a. Sebagian besar reponden tidak melakukan deteksi dini kanker leher rahim yaitu 295 responden $(81,5 \%)$ dari 362 responden seluruhnya, dan usia responden yang beresiko sebanyak $245(64,4 \%)$, pendidikan $\begin{array}{lllll}\text { rendah } & 104 \quad(56,4 \quad \%) & \text { yang }\end{array}$ bekerja.Responden dengan status sosial ekonomi yang rendah sebanyak 234 $(64,6 \%)$, responden yang mendapat dukungan suami sebanyak 185 (51,5\%) dan yang mempunyai sikap negatif sebanyak $188(51,9 \%)$. Sebagian besar responden memiliki pengetahuan baik sebanyak 355 $(98,1 \%)$. Sebanyak $210(58,0 \%)$ responden mengatakan mendapat informasi tentang kanker leher rahim dan yang 225 responden $(62,2 \%)$ mengatakan kader kesehatan 
berperan dalam deteksi dini kanker leher rahim. Sebanyak $200(55,2 \%)$ responden mengatakan malu dalam melakukan deteksi dini kanker, dan $110(30,4 \%)$ mengatakan takut jika melakukan deteksi dini kanker leher rahim.

b. Pada hasil analisa bivariat, menunjukkan ada hubungan usia ( $p$-value 0,042; OR 0,5), pendidikan ( $p$-value 0,$001 ;$ OR 2,5), pekerjaan ( $p$-value < 0,001 ; OR 2,8), status sosial ekonomi keluarga ( $p$-value $<0,001$; OR 6,8), sikap (p-value 0,025; OR 1,9), informasi yang didapat ( $p$-value 0,001 ; OR 2,7 ), peran kader ( $p$-value 0,013 ; OR 2,2), rasa malu ( $p$-value 0,001 ; OR 2,8 ), rasa takut menerima diagnose kanker leher rahim ( $p$-value < 0,001; OR 7,9) dengan deteksi dini kanker leher rahim di wilayah kecamatan Gisting kabupaten Tanggamus Lampung tahun 2016. Tidak ada hubungan dukungan suami (p-value 1,000), pengetahuan $(p$-value 0,357$)$ dengan deteksi dini kanker leher rahim di wilayah kecamatan Gisting kabupaten Tanggamus lampung tahun 2016.

\section{DAFTAR PUSTAKA}

Adi. 2011. Wanita dan Deteksi Dini Kanker Serviks. Acta Diurna vol 7 No 2.

Adler. Mortimer J. 2011. How to read a book:The classic guide to intellegent reading. United States.

Direktorat Pengadilan Penyakit Tidak Menular. 2013. Pencegahan Kanker Payudara dan Kanker Leher Rahim. Jakarta: Kementerian Kesehatan Republik Indonesia Direktur Jenderal PP\&PL.

Friedman, M.M. 2010. Buku Ajar Keperawatan Keluarga Riset, Teori dan Praktik. Edisi kelima. Jakarta: EGC.

Gustiana, Yulia Irvani Dewi, Sofiana Nurchayati. 2013. Faktor-faktor yang Berhubungan dengan Perilaku Pencegahan Kanker Servix pada Wanita Usia Subur. Jurnal Kesehatan.

Husada, Dian. 2011. Promosi Kesehatan "Health Belief Model (Model Kepercayaan Kesehatan)". http://ninikdianhusada.blogspot.co.id/p/hea lth-belief-model.html (online diakses pada 25 Maret 2016).

Kementrian Kesehatan RI. 2015. Situasi Penyakit Kanker. Pusat data dan Informasi kementrian kesehatan RI 2015. Jakarta. c. Variabel paling dominan berhubungan dengan deteksi dini kanker leher rahim di wilayah kecamatan Gisting kabupaten Tanggamus Lampung tahun2016 adalah status ekonomi dengan $p$-value $<0,001$; OR 6,8 .

\section{SARAN}

a. Mensosialisasikan kepada masyarakat bahwa pemeriksaan IVA dan Papsmear bagi peserta BPJS kesehatan adalah gratis, dan lebih banyak melakukan kegiatan bakti sosial dengan mengadakan pemeriksaan IVA gratis bagi seluruh masyarakat yang ada diwilayah kecamatan Gisting kabupaten tanggamus.

b. Lebih meningkatan penyuluhan dengan menghadirkan teman atau kerabat yang dikenal masyarakat yang sudah melakukan deteksi dini kanker leher rahim atau penderita kanker leher rahim sehingga timbul kepercayaan masyarakat untuk melakukan deteksi dini kanker leher rahim.

Linadi. 2013. Dukungan suami mendorong keikutsertaan PapSmear Pasangan Usia Subur (PUS) di Perumahan Puncak Gading Semarang. Jurnal Kesehatan Reproduksi Vol 4 no 2, Agustus 2013: 61-71.

Mahaarsie, Lesse. Indarwati. 2012. Hubungan Pengetahuan tentang Kanker Serviks dengan Keikutsertaan Ibu melakukan IVAtest di Kelurahan Jebres Surakarta. Gaster Vol 9 no 2 Agustus 2012.

Martini. 2013. Hubungan karakteristik, pengetahuan dan sikap wanita pasangan usia subur dengan tinakan pemeriksaan papsmear di Puskesmas Sukawati II. Tesis. Program Pasca sarjana Universitas Udayana Denpasar.

Notoatmodjo Soekidjo. 2011. Kesehatan Masyarakat Ilmu dan Seni. Jakarta: Rineka Cipta.

Notoatmodjo, Soekidjo. 2014. Kesehatan Masyarakat Ilmu dan Seni. Jakarta: Rineka Cipta.

Sabrina, Setiawati, Wahidin. 2015. Situasi Penyakit Kanker.. Data dan Informasi Kesehatan.

Saslow,Et.al. 2012. American Cancer Society, American Society for coloscopy and society for clinical pathology screenly 
guidelines for the preventor and early detection of cervical cancer. National Institutes of health. CA Cancer J Clin. 2012;62(3):147-172.

Doi:10.3322/caac.21139.

Schiffman \& Solomon. 2013. Servical Cancer Screamy with Homan Papilloma virus and Cytolocig Cotesting. The New England Journal Of Medicine.

Sulistiowati, Eva, Anna Maria Sirait. 2014. Pengetahuan Tentang Faktor Resiko Perilaku dan Deteksi Dini Kanker Serviks dengan Inspeksi Asam Asetat (IVA) pada
Wanita di Kecamaatan Bgor Tengah kota Bogor. Pusat Teknologi Intervensi Kesehatan Masyarakat Badan Penelitian dan Pengembangan Kesehatan Kementrian Kesehatan RI. Buletin Peneliti Kesehatan Vol 42, No 3, September 2014: 193-202.

Rasjidi. 2009. Epidemiologi Kanker Serviks. StudyPustaka Divisi Ginekologi Onkologi Fakultas Kedokteran Universitas Pelita Harapan Tanggerang. Indonesian Journal of Cancer Vol III, no 3 Juli-September 2009. 